\title{
PENGENTASAN SURABAYA BEBAS ODF DENGAN MEMBERIKAN PERCONTOHAN WC ANTI BAU DAN ANTI PENUH DI KELURAHAN JAGIR WONOKROMO
}

\section{(ERADICATION OF ODF-FREE SURABAYA BY PROVIDING PILOT OF ANTI-ODOR AND ANTI-FULL WC IN JAGIR WONOKROMO)}

\author{
Herry Agoes Hermadi ${ }^{1}$, Sunaryo Hadi Warsito ${ }^{2}$ \\ ${ }^{1}$ Departemen Reproduksi Veteriner, ${ }^{2}$ Departemen Produksi Ternak Fakultas Kedokteran \\ Hewan Universitas Airlangga \\ e-mail: herry-a-h@fkh.unair.ac.id
}

\begin{abstract}
The aim of the 2019 KKN BBM Community Service Program is to overcome the problems found in the Surabaya Urban area Jagir Wonokromo, namely the low capacity of the people's economic income, low knowledge and understanding of environmental management, environmental hygiene, especially health, defecation, which deserves to be called ODF. (open defecation free) which only uses public toilets in a small closed channel this seems the same as ODF. The solution is for the residents to be able to overcome ODF problems. Training and mentoring are conducted by KKN students in how the methods and methods carried out in communities that have been developed are used for deodorizing and at the same time destroying human excrement as a biofermentor that will be inserted into septic tanks containing feces so that the process of crushing the stool quickly and immediately eliminating pungent odors and circulating septic tanks into groundwater and not polluting the environment. With the pilot of Anti-Odor and Anti-Fully WC in Jagir Wonokromo Kelurahan, it is expected that there will be a change in the low level of knowledge and understanding of environmental management and environmental cleanliness, especially the health of defecation methods that are worth mentioning as not yet ODF which only uses closed public lavatories. As a solution is the Citizens to be able to overcome the ODF problem by building a toilet independently later and will have a sense of shame and obedience to environmental cleanliness.
\end{abstract}

Keywords: Jagir Wonokromo, KKN PPM, WC Anti Odor

\begin{abstract}
abstrak
Tujuan Program Pengabdian Masyarakat KKN BBM 2019 ini adalah untuk mengatasi masalah yang dijumpai di daerah Perkotaan Surabaya Kelurahan Jagir Wonokromo, yaitu rendahnya kapasitas pendapatan ekonomi warga, rendahnya akan pengetahuan dan pemahaman tentang pengelolaan lingkungan kebersihan lingkungan terutama kesehatan cara buang air besar yang layak disebut belum ODF (open defecation free) yang hanya menggunakan wc umum secara tertutup kesaluran kecil hal ini nampaknya sama saja dengan ODF. Sebagai solusinya adalah Warga untuk dapat mengatasi masalah ODF. Dilakukan pelatihan dan pendampingan oleh mahaswiswa KKN bagamana cara dan metoda yang dilakukan di masyarakat yang sudah berkembang digunakkan penghilang bau dan sekaligus penghancur kotoran Manusia sebagai biofermentor yang akan dimasukkan kedalam septic tank yang berisi tinja agar terjadi proses penghancuran tinja secara cepat dan langsung menghilangkan bau yang menyengat dan mengalirkkan septik tank ke dalam air tanah dan tidak mencemari lingkungan. Dengan adanya percontohan WC Anti Bau Dan Anti Penuh Di Kelurahan Jagir Wonokromo di harapkan terjadi perubahan rendahnya akan pengetahuan dan pemahaman tentang pengelolaan lingkungan $\mathrm{k} 3$ ebersihan lingkungan terutama kesehatan cara buang air besar yang layak disebut belum ODF yang hanya menggunakan wc umum secara tertutup. Sebagai solusinya adalah Warga untuk
\end{abstract}


dapat mengatasi masalah odf dengan melakukan pembangunan wc secra mandiri kelak dan akan mempunyai rasa malu dan patuh terhadap kebersihan lingkungan.

Kata Kunci: Jagir Wonokromo, KKN PPM, WC Anti Bau

\section{PENDAHULUAN}

Program Pengabdian Masyarakat KKN BBM ini adalah untuk mengatasi masalah yang dijumpai di daerah Perkotaan Surabaya Kelurahan Jagir Wonokromo, yaitu rendahnya kapasitas pendapatan ekonomi warga, rendahnya akan pengetahuan dan pemahaman tentang pengelolaan lingkungan $k 3$ ebersihan lingkungan terutama kesehatan cara buang air besar yang layak disebut belum ODF (open defecation free) yang hanya menggunakan wc umum secara tertutup kesaluran kecil hal ini nampaknya sama saja dengan ODF. Sebagai solusinya adalah Warga untuk dapat mengatasi masalah ODF. Program Pengabdian Masyarakat adalah kegiatan akademik bagi para mahasiswa yang dapat dilakukan pada tingkat semester tertentu. Sebagai bagian dari pengabdian kepada masyarakat Universitas Airlangga, adalah bentuk pendidikan kepada masyarakat oleh mahasiswa. Sesuai namanya, kegiatan ini mengandung dimensi pembelajaran (learning) yang dilakukan di lokasi, di mana masyarakat terlibat (bersama masyarakat). Dimensi lain, interaksi dengan masyarakat diharapkan memberi manfaat bagi masyarakat. Sebagai bagian integral dari masyarakat dan bangsa, pelaksanaan adalah suatu bentuk komitmen Universitas Airlangga untuk mengimplementasikan keilmuanya yang dibimbing oleh dosen yang ada hubunganya dengan keilmuan masing2 mahasiswa dengan lokasi wilayah tidak jauh dari Universitas Airlangga.

Problem lingkungan akan menjadi Salah satu permasalahan yang perlu mendapat perhatian serius dari berbagai pihak adalah sanitasi. Masyarakat yang buang air besar sembarangan merupakan salah satu dari penyebab buruknya sanitasi di Indonesia yaitu masih banyaknya. Semakin parah kondisi tersebut seirama dengan sulitnya masyarakat untuk memperoleh kemudahan jamban sehat. Meskipun ada uang yang harus dikeluarkan tergolong mahal sehingga umumnya masyarakat tidak mampu untuk mencapainya. Sebab itu pengabdian ini akan mencoba untuk menganalisis desain jamban yang saat ini ada di masyarakat dan kemudian mengembangkan desain jamban yang bekerja sama dengan mitra baru yang memenuhi kriteria jamban sehat dan juga memiliki harga yang terjangkau. Usaha untuk meningkatkan keterpaduan dan sinkronisasi berbagai pihak yakni Perguruan Tinggi Universitas Airlangga, masyarakat, lembaga pemerintah, lembaga swasta, serta mitra kerja dalam usaha pemberdayaan masyarakat melalui aktivitas.

Kelurahan Jagir Wonokromo mempunyai 11 Rukun warga dimana terdapat banyak warga miskin yang tinggal di sebagian tanah PJKA Surabaya merupakan sebagian daerah Kumuh dan padat penduduk dengan komposisi 5.000 penduduk miskin. Tujuan program ini adalah untuk mengatasi masalah yang dijumpai di daerah Perkotaan sepanjang pinggir sungai di Surabaya. yaitu rendahnya pendapatan warga, rendahnya pengetahuan dan pemahaman tentang pengelolaan lingkungan terutama kesehatan cara buang air besar yang layak disebut ODF (open defecation) yang hanya menggunakan wc secara tertutup tetapi hanya disalurkan kesaluran kecil hal ini nampaknya sama saja dengan ODF. Warga biasa membuang hajad di rel-rel kereta api. 
Kelurahan Jagir Wonokromo dilakukan pelatihan dan pendampingan bagaimana cara memurnikan limbah Rumah potong hewan di Surabauya dalam bentuk isi rumen dilakukan penanaman atau cultur dengan tetes tebu atau layak disebut molasses dan didiamkan selama 1minggu agar kuman berkembang.Jika sudah berkembang digunakkan sebagai cairan biofermentor yang akan dimasukkan kedala septic tank yang berisi tinja agar terjadi proses penghancuran tinja secara cepat dan langsung menghilangkan bau yang menyengat dan mengalirkkan Salah satu upaya untuk mengurangi limbah rumah potong hewan ketempat pembuangan akhir adalah memanfaatkan limbah tersebut untuk pembuatan kompos dan biofermentor kering atau basah.Hal tersebut dilakukan karena lokasi pembuangan limbah RPH sangatlah jauh dan biaya pembuangan cukup mahal. Biaya operasional ini biasanya digunakan dengan hal hal yang produktip misalnya untuk membuat pupuk organic secara cepat, pembuatan pakan hewan yang dikelola kembali mengingat isi rumen mempunyai potensi protein yang cukup dalam jumlah yang sangat besar untuk itu. Kapasitas hasil produksi 2 ton perhari sangat berpotensi mengganggu lingkungan. Produk lain yang cukup menjanjikkan adalah produk biofermentor yang dapat diformulasikkan dalam bentuk cair dan kering. Kegunaan biofermentor ini sangatlah ramah lingkungan mengingat dapat digunakan untuk biofermentasi tanah untuk menyuburkan tanah atau dapat digunakkan sebagai pengganti pupuk untuk menggemburkkan tanah mengingat kandungan mikroba dan unsur hara NPK dalam isi rumen.

Pada model pengabdian Masyarakat PKM dibutuhkkan kecermatan berfikir dengan menggunakkan biofermentor sebagai penghancur tinja sangatlah tepat mengingat penduduk kota Surabaya yang banyak sekitar 2 juta orang tentu membutuhkkan produk biologis semacam ini. Konsep dasar open defecation free (ODF)/buang air besar sembarangan (babs)Perilaku buang air besar sembarangan (BABS/Open defecation) termasuk salah satu contoh perilaku yang tidak sehat. BABS/Open defecation adalah suatu tindakan membuang kotoran atau tinja di ladang, hutan, semak - semak, sungai, pantai atau area terbuka lainnya dan dibiarkan menyebar mengkontaminasi lingkungan, tanah, udara dan air.

Manusia mengeluarkan tinja rata - rata seberat 100 - 200 gram per hari, namun berat tinja yang dikeluarkan tergantung pola makan. Setiap orang normal diperkirakan menghasilkan tinja rata-rata sehari sekitar 85 - 140gram kering perorang/ hari dan perkiraan berat basah tinja manusia tanpa air seni adalah 135 - 270gram perorang/hari. Dalam keadaan normal susunan tinja sekitar $3 / 4$ merupakan air dan $1 / 4$ zat padat terdiri dari 30\% bakteri mati, $10-20 \%$ lemak, $10-20 \%$ zat anorganik, $2-3 \%$ protein dan $30 \%$ sisa - sisa makanan yang tidak dapat dicerna. Tinja adalah bahan buangan yang dikeluarkan dari tubuh manusia melalui anus sebagai sisa dari proses pencernaan makanan di sepanjang sistem saluran pencernaan. Dalam aspek kesehatan masyarakat, berbagai jenis kotoran manusia yang diutamakan adalah tinja dan urin karena kedua bahan buangan ini dapat menjadi sumber penyebab timbulnya penyakit saluran pencernaan. Permasalahan yang Timbul Akibat Tinja. Tinja manusia mengandung puluhan miliar mikroba, termasuk bakteri koli-tinja. Sebagian diantaranya tergolong sebagai mikroba patogen, seperti bakteri Salmonela typhi penyebab demam tifus, bakteri Vibrio cholerae penyebab kolera, virus penyebab hepatitis A, dan virus penyebab polio. Tingkat penyakit akibat kondisi sanitasi yang buruk di Indonesia sangat tinggi. Bapennas menyebutkan, tifus mencapai 800 kasus per 100.000 penduduk. 
Sedangkan polio masih dijumpai, walaupun dinegara lain sudah sangat jarang. Materi Organik Kotoran manusia (tinja) merupakan sisi dan ampas makanan yang tida $\mathrm{k}$ tercerna. Ia dapat berbentuk karbohidrat, dapat pula protein, enzim, lemak, mikroba dan sel-sel mati. Satu liter tinja mengandung materi organik yang setara dengan 200-300 mg BODS (kandungan bahan organik). Telur Cacing Seseorang yang cacingan akan mengeluarkan tinja yang mengandung telu-telur cacing. Beragam cacing dapat dijumpai di perut kita. Sebut saja, cacing cambuk, cacing gelang, cacing tambang, dan keremi. Satu gram tinja berisi ribuan telur cacing yang siap berkembang biak diperut orang lain. Anak cacingan adalah kejadian yang biasa di Indonesia. Penyakit ini kebanyakan diakibatkan cacing cambuk dan cacing gela ng. Prevalensinya bisa mencapai 70 persen dari balita. Nutrien Umumnya merupakan senyawa nitrogen $(\mathrm{N})$ dan senyawa fosfor (P) yang dibawa sisa-sisa protein dan sel-sel mati. Nitrogen keluar dalam bentuk senyawa amonium, sedangkan fosfor dalam bentuk fosfat. Satu liter tinja manusia mengandung amonium sekitar $25 \mathrm{gram}$ dan fosfat seberat $30 \mathrm{mg}$. Senyawa nutrien memacu pertumbuhan ganggang (algae). Akibatnya, warna air menjadi hijau. Ganggang menghabiskan oksigen dalam air sehingga ikan dan hewan lainnya mati.

\section{METODE PENGABDIAN MASYARAKAT}

Pada model pengabdian Masyarakat KKN PPM Warga Di Kelurahan Jagir Wonokromo. dibutuhkkan kecermatan berfikir dengan menggunakkan biofermentor sebagai penghancur tinja sangatlah tepat mengingat penduduk kota Surabaya yang banyak sekitar 2 juta orang tentu membutuhkkan produk Septik Tank semacam ini.

Tahap tahap Pendahuluan dan Persiapan. Pada tahap ini dilakukan ijin lokasi dari dinas kelurahan setempat dan langsung melakukan pemilihan lokasi dan dilakukan survey lapangan serta negosiasi dengan Lurah Jagir Wonokromo dan mitra Kader Lingkungan Kelurahan Kecamatan. Wonokromo Surabaya.

Pemberian pemaqntapan dan Pembekalan materi tentang kesling pada mahasiswa KKN. Pembekalan materi dibagi 2 yaitu materi umum dan materi substansi. Materi umum disajikan dalam bentuk teori meliputi: a. sebagai salah satu wujud implementasi tridharma PT. b. Wawasan kebangsaan c. Etika dan tata karma di masyarakat, d. Pemerintahan Kelurahan dan Ketua RW IV Kedungbaruk Kecamatan Rungkut Materi substantif diberikan secara teori dan praktek meliputi a. Teknologi budidaya tanaman dengan system vertikultur a. Teknologi sistem integrasi penanganan limbah isi rumen di RPH penggirian Surabaya b. Teknologi pembuatan WC dengan septic tank 3 Tabung

Pelaksanaan KKN PPM di Kelurahan Jagir Wonokromo di Surabaya. Kelompok sasaran diharapkan: Berpartisipasi aktif dalam sosialisasi program kegiatan. Berpartisipasi aktif dalam pemanfaatan lahan pekarangan rumahnya untuk program sistem integrasi. Berpartisipasi aktif dalam pembuatan WC dan membiasakan diri dalam membuang kotoran tidak disungai 'Berpartisipasi aktif dalam aplikasi WC 3 tabung dan Pemberian Biofermentor 


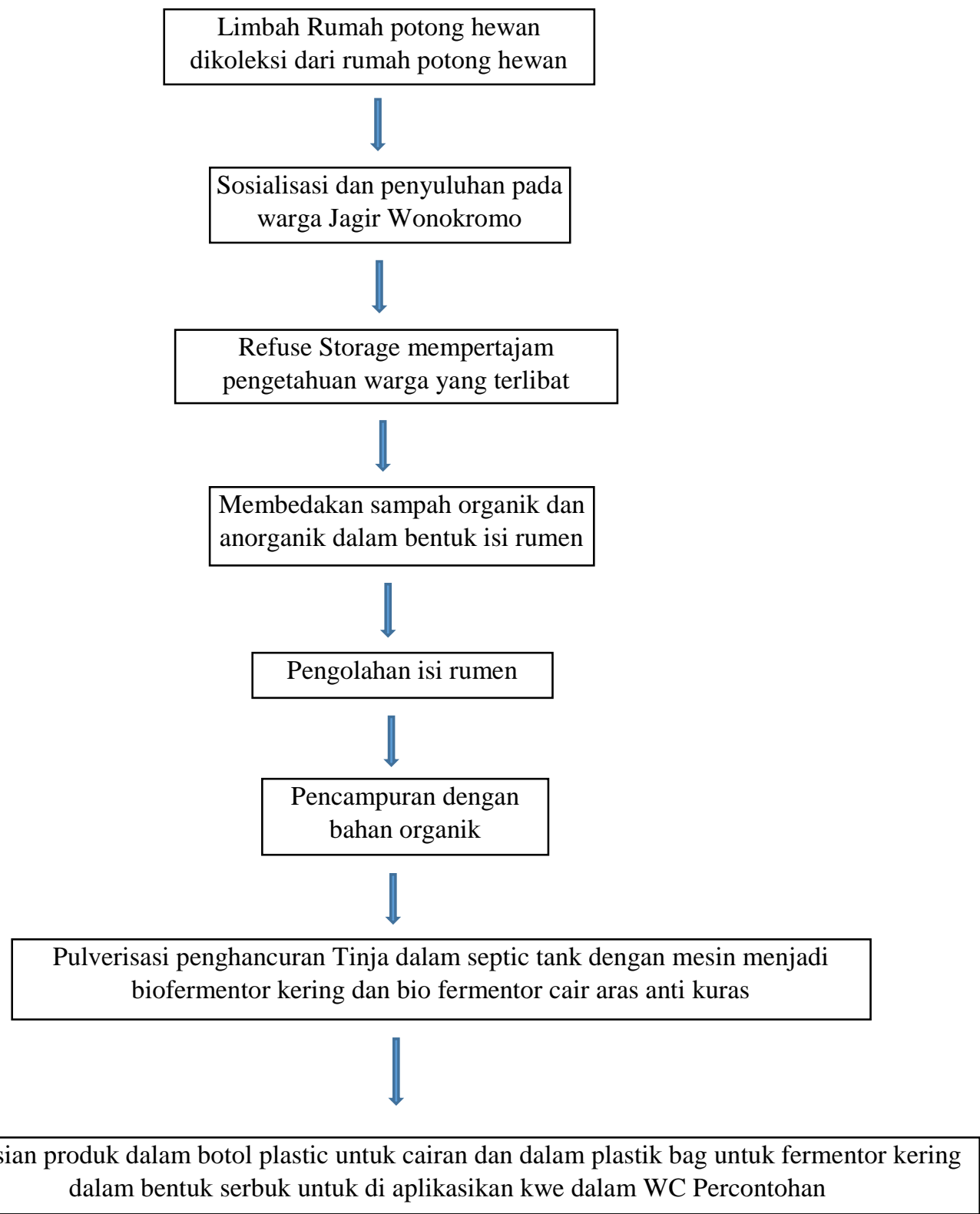

Rencana keberlanjutan program ini adalah tergantung pada aktivasi warga dan kader lingkungan Warga Masyasrakast Jagir Wono Kromo

\section{HASIL DAN PEMBAHASAN}

Pembangunan WC dengan septic tank dan closet telah dilakukan di Kelurahan Masyarakat Jagir Wonoromo sangat membutuhkkan WC dengan septic tank yang tidak mudah penuh dan anti bau sebanyak 4 Unit Pembangunan berikut renovasi dan plengsengan wc serta perbaikkan pintu wc dan beberapa septic tank. Di WC Umum masding2 dicetak septic tank ukuran besar beserta resapan. Sehingga tidk ada lagi tinja deisembarang tempat, Disamping pemberian mikroba dan penghancur tinja dalam septic tank. Masyarakat yang buang air besar sembarangan merupakan salah satu dari penyebab buruknya sanitasi di Indonesia yaitu masih banyaknya orang buang hajat kesungai. Jarak 10 meter antara tangki septic (septic tank) dan sumur telah menjadi pengetahuan umum 
dan populer di masyarakat. Alasannya, agar air sumur tidak terkontaminasi dengan air tangki septic oleh bakteri patogen yang dapat mengganggu kesehatan. Alasan demikian tentu tidak salah. Hanya, dalam kenyataannya jarak 10 meter, terutama pada rumah-rumah padat penduduk atau perumahan type RSS, jarak sejauh itu sangat sulit diperoleh. Bisa saja terjadi antara sumur dan tangki septic di suatu rumah berjarak 10 meter, tetapi dengan tangki septic tetangga sebelah jaraknya kurang dari 10 meter. Munculnya kemestian jarak 10 meter sumur dan tangki septic bermula dari bakteri E-coli patogen (bersifat anaerob) yang biasanya mempunyai usia harapan hidup selama tiga hari. Sedangkan kecepatan aliran air dalam tanah berkisar 3 meter per hari (rata-rata kecepatan aliran air dalam tanah di pulau jawa 3 meter/hari), sehingga jarak ideal antara tangki septic dengan sumur sejauh 3 meter per hari x 3 hari $=9$ meter. Akan tetapi, mengapa harus dibuat 10 meter? Dari hasil perhitungan, jarak tempuh bakteri selama 3 hari hanya 9 meter. Adapun angka 10 meter setelah ditambah satu meter sebagai jarak pengaman. Itulah sekilas kisah angka 10 untuk jarak antara sumur dengan tangkiseptic. Bagaimana jika kurang dari 10 meter? Apabila ingin membuat tangki septic, sementara jarak antara sumur dan tangki septic yang ingin dibuat kurang dari 10 meter, tidak perlu bingung. Ketahuilah dulu arah aliran air tanah yaitu dengan cara melihat sumur tetangga.

\begin{tabular}{lll}
\hline No & Pihak yang terlibat & Keterlibatan \\
\hline 1 & Warga Kelurahan Jagir & Berpartisipasi mengikuti semua program \\
& Menyediakan lahan pekarangan pinggir sungai \\
& Wonokromo & Menyediakan tempat pelatihan dan penyuluhan \\
& Menyediakan limbah isis rumen sapi \\
& Melaksanakan program yang dilatihkan Bersama \\
& dengan bimbingan mahasiswa \\
& Melakukan sosialisasi Program, KKN BBM \\
& Melakukan penyuluhan materi program \\
& Melakukan Pelatihan dan Pendampingan Program \\
& Membuat Rencana Pengabdian \\
& Masyarakat Kepada \\
& Melakukan pembekalan materi umum maupun \\
& materi KN Bnair & substansi baik teori maupun praktek \\
& Pengurusan ijin, Sutvey lokasi \\
& Negosiasi dengan mitra \\
& Penentuan dan pembimbingan DPL \\
& Partisipasi dana Pengabdian pada mayarakat \\
& Monitoring dan evaluasi \\
\end{tabular}

Semakin parah kondisi lingkungan di daerah kaum pendatang yang tinggal di daerah Kecamatan Rungkut seirama dengan sulitnya masyarakat untuk memperoleh kemudahan jamban sehat. Meskipun ada uang yang harus dikeluarkan tergolong mahal sehingga umumnya masyarakat tidak mampu untuk mencapainya. Sebab itu pengabdian ini akan mencoba untuk menganalisis desain jamban yang saat ini ada di masyarakat dan kemudian mengembangkan desain jamban yang bekerja sama dengan mitra baru yang 
memenuhi kriteria jamban sehat dan juga memiliki harga yang terjangkau. Problem lingkungan akan menjadi Salah satu permasalahan yang perlu mendapat perhatian serius dari berbagai pihak adalah sanitasi. Buatlah gambar garis segitiga yang menghubungkan ketiga titik sumur tetangga tersebut di atas kertas. Ukurlah kedalaman sumur-sumur tetangga, cukup 3 rumah saja. Dari gambar dapat diketahui, sumur yang paling dangkal menunjukkan arah aliran menuju ke sumur tersebut Masing-masing titik sumur diberi notasi kedalamannya (perhitungan kedalaman diukur dari muka air hingga ke permukaan tanah).

Dari cara tersebut dapat diketahui bahwa jarak sumur yang kurang dari 10 meter tidaklah masalah, asalkan kita mengetahui arah aliran air tanah dengan cara seperti di atas. Dengan demikian, yang harus kita lakukan adalah meletakkan tangki septic di mana arah alirannya tidak mengarah ke sumur, berarti harus sebaliknya. Lebih baik lagi apabila arah aliran air tanah tersebut berasal dari sumur menuju ke tangki septic, tetapi jangan sebaliknya. Di samping arah aliran air tanah yang perlu kita ketahui, kecepatan aliran air tanah tidak kalah pentingnya. Walaupun berdasarkan pengalaman kecepatan aliran air tanah di pulau Jawa rata-rata 3 meter/hari, tidak menutup kemungkinan masing-masing daerah di Pulau Jawa pun mempunyai kecepatan aliran air tanah yang berbeda. Hal ini tergantung dari formasi batuan pada daerah tersebut. Walaupun arah aliran dari tangki septic menuju ke sumur, kecepatan aliran air tanah hanya 1 meter/hari, maka jarak ideal antara sumur dan tangki septic hanya 4 meter. adalah Bakteri ramah lingkungan yang menguntungkan bagi tangki septic atau septectank, yang mempunyai manfaat yang sungguh sangat menakjubkan dalam mengatasi berbagai masalah seperti : bau, cepat penuh, macet, buntu, sulit disiram dalam septictank dan dapat berfungsi sebagai berikut: Dalam menguraikan limbah padat secara efektif pada tangki Septic (Septictank)' Sangat EFEKTIF membunuh kuman penyebat penyakit/pathogen, seperti Disentri, Diare, Kholeram, dan TipesKeuntungan menggunakan: Dalam waktu 1 (satu) bulan septictank akan SEGERA terkuras $80 \%$ menjadi air $\left(\mathrm{H}_{2} \mathrm{O}\right)$ \& menjadi GAS atau $\mathrm{CO}_{2}$ (tidak berbau )Menghilangkan bau tak sedap pada septictank. Mengatasi septictank yang MACET. Merupakan SOLUSI yang tepat septictangk yang CEPAT PENUH. Menjaga KUALITAS SUMUR yang posisinya berdekatan dengan sptictank

\section{Mikroba Penghancur dan Pengilang Bau Tinja Septic Tank (WC)}

Merupakan hasil rekayasa bioteknologi dibidang mikroorganisme lingkungan, dengan konsep dasar inokulasi mikroba penghancur dan penhilang bau tinja Hasil riset Prof Dr Herry Agoes Hermadi dan Koen Irianto SH. MM dari Universitas Airlangga dengan activator kultur campuran mikroorganisme non pathogen (probiotik), sehingga sangat efektif sebagai pemicu penguraian limbah organic menjadi material yang bermanfaat bagi lingkungan, sehingga mampu mempercepat penghancuran dan penghilang bau WC anda dibangun oleh beberapa strain mikroba non pathogen, antara lain: Megatorium Sp., Azobacter Sp., Lactobacillus Sp., Nitrobacter, Yeast, Streptomyces, Actinomycetes, Subtillis sp, Micrococus Sp Ruminococus dan Bakteroidessuccinogenes cellulose, sp mikroorganisme menguntungkan lainnya dalam jumlah yang lebih kecil. jika diaplikasikan sebagai inokulan, akan memicu percepatan proses penguraian tinja sehingga mampu mencegah terbentuknya gas-gas beracun misalnya: metana, amoniak, hydrogen sulfide $\left(\mathrm{H}_{2} \mathrm{~S}\right)$. Aturan pakai masukkan 1 botol kemasan 1 liter sebulan sekali kedalam wc hindarkan penggunaan bahan kimia pembersih apapun kedalam lubang wc dan saat cebok jangan menggunakan sabun 
antiseptic yang langsung dimasukkan kedalam WC anda tapi gunakkan sabun tepat diatas lantai kamar mandi agar Mikroba penhancur tinja akan tetap tumbuh subur. Keuntungan: Menekan potensi pencemaran lingkungan dan mempersiapkan dekomposisi limbah organic. penghancuran dan penghilang bau WC anda sehinga tidak mudah penuh. Meningkatkan ketersediaan unsur hara dan nutrisi alam. Memperbaiki sifat, kimia dan biologis air limbah septic tank. Menstabilkan $\mathrm{pH}$ tanah dan parameter kualitas air septic tank. Bila diaplikasikan pada sector limbah septic tank menghilangkan mikroba pathogen.

\section{PENUTUP}

\section{Simpulan}

Masyarakat Kelurahan Jagir Wonoromo sangat membutuhkkan WC dengan septic tank yang tidak mudah penuh dan anti bau. Dibutuhkkan partisipasi pemerintah Kota untuk memsubsidi sebagian biaya pembuatan WC bagi warga yang kurang mampu.

\section{Saran}

Swasembada pembuatan Wc diharapkkan pada setiap warga miskin sangatlah diperlukan guna menunjang kebersihan dan nilai estetika warga dan menjaga kesehatan lingkungan di perkotaan kususnya Masyarakat Kelurahan Jagir Wonoromo

\section{Ucapan Terima Kasih}

Tim pengabdian kepada masyarakat mengucapkan terima kasih atas bantuan pendanaan dari Direktorat Riset dan Pengabdian Masyarakat, Direktorat Jenderal Penguatan Riset dan Pengembangan, Kementerian Riset, Teknologi dan Pendidikan Tinggi sesuai dengan Surat Perjanjian Pendanaan Program Pengabdian Kepada Masyarakat. Tim pengabdian kepada masyarakat juga mengucapkan terima kasih kepada pimpinan institusi terkait atas bantuan kelancaran kegiatan pengabdian kepada masyarakat ini.

\section{DAFTAR PUSTAKA}

Angoli, T. 2000. Hydrogen peroxide not recommended to unclog failed drainfields. Small Flows Quarterly Vol. 1 No. 2, p. 42-44. http://www.nesc.wvu.edu/nsfc/pdf/SFQ/SFQsp00.pdf

Bowne, W.C. 1990. Audit of Septage Accumulation on the Glide, Oregon STEP Pressure Sewer System,

Dow, D., and G. Loomis. 1999. Septic Tank Additives. University of Rhode Island Cooperative Extension Service Onsite Wastewater Training Center, Kingston, RI. http://www.uri.edu/ce/wq/owtc/html/owtc_sepadd.html

Environmental Protection Agency. n.d. Septic Tank Additives. Onsite Wastewater Treatment Systems Special Issues Fact Sheet 1. EPA 625/R-00/008. http://www.epa.gov/nrmrl/pubs/625r00008/html/html/fs1.htm 
EPA. U.S. 1984. Alternative Wastewater Collection Systems. EPA/625/1-91/024, 1991. 7. Winneberger, J.H.T. Septic Tank Systems, a Consultant's Toolkit. Butterworth Publishers,

Penerapan Metode Value Engineering Pada Pengembangan Desain Jamban Sehat dan Ekonomis (Studi Kasus : Pengusaha Sanitasi Jawa Timur) Muhammad Jefi Nur Cahyono dan Ir. Lantip Trisunarno, MT. Teknik Industri, Fakultas Teknologi Industri, Institut Teknologi Sepuluh Nopember (ITS) Jl. Arief Rahman Hakim, Surabaya60111 E-mail : trisunarno@yahoo.com

Olson, K., D. Gustafson; B. Liukkonen; and V. Cook. 1997. Septic System Owner's Guide: Use and Operation. Publication PC-06583. University of Minnesota, College of Agricultural, Food, and Environmental Sciences, St. Paul, MN. http:// www.extension.umn.edu/distribution/naturalresources/components/6583-04.html 